\title{
New azhdarchoid pterosaur (Pterosauria, Pterodactyloidea) with an unusual lower jaw from the Portezuelo Formation (Upper Cretaceous), Neuquén Group, Patagonia, Argentina
}

\author{
ALEXANDER W.A. KELLNER ${ }^{1}$ and JORGE O. CALVO ${ }^{2}$ \\ ${ }^{1}$ Laboratório de Sistemática e Tafonomia de Vertebrados Fósseis, Departamento de Geologia e Paleontologia, Museu Nacional/ \\ Universidade Federal do Rio de Janeiro, Quinta da Boa Vista, São Cristóvão, 20940-040 Rio de Janeiro, RJ, Brazil \\ ${ }^{2}$ Grupo de Transferencia Proyecto Dino, Universidad Nacional del Comahue, Parque Natural Geo- \\ Paleontológico Proyecto Dino, Ruta Provincial 51, Km 65, Neuquén, Argentina
}

Manuscript received on June 22, 2017; accepted for publication on September 4, 2017

\begin{abstract}
A new azhdarchoid pterosaur from the Upper Cretaceous of Patagonia is described. The material consists of an incomplete edentulous lower jaw that was collected from the upper portion of the Portezuelo Formation (Turonian-Early Coniacian) at the Futalognko site, northwest of Neuquén city, Argentina. The overall morphology of Argentinadraco barrealensis gen. et sp. nov. indicates that it belongs to the Azhdarchoidea and probable represents an azhdarchid species. The occlusal surface of the anterior portion is laterally compressed and shows blunt lateral margins with a medial sulcus that are followed by two welldeveloped mandibular ridges, which in turn are bordered laterally by a sulcus. The posterior end of the symphysis is deeper than in any other azhdarchoid. This unique construction of the lower jaw suggests the existence of an elaborate interlocking mechanism with the upper jaw. Furthermore, although speculative, it is advocated here that Argentinadraco barrealensis might have used the lower jaw to obtain its prey by cutting or ploughing through unconsolidated sediment in shallow waters, a feeding behavior not previously proposed for pterosaurs.
\end{abstract}

Key words: Pterosauria, Pterodactyloidea, Argentinadraco, Patagonia, feeding behavior, Cretaceous.

\section{INTRODUCTION}

Pterosaur specimens are found in several deposits around the world (e.g., Barrett et al. 2008) but in most cases they are incomplete and fragmentary (e.g., Wellnhofer 1991, Codorniú and Gasparini 2007, Rodrigues and Kellner 2013). These volant archosaurs have been recovered from predominantly coastal or marginal marine

Correspondence to: Alexander W.A. Kellner

E-mail: kellner@mn.ufrj.br environments (Kellner 1994, Wang et al. 2005) and typical inland deposits are not very common (e.g., Bakhurina and Unwin 1995, Manzig et al. 2014). Among the most important continental sites with pterosaur remains are the Late Jurassic Tiaojishan Formation (e.g., Sullivan et al. 2014, Wang et al. 2015), the Early Cretaceous Yixian and Jiufotang formations (e.g., Lü and Ji 2006, Wang and Zhou 2006, Wang et al. 2012), the Lower Cretaceous deposits of the Tugulu Group (Wang et al. 2014), the Albian Lagarcito Formation (Bonaparte 1971, 
Chiappe et al. 2000, Codorniú and Chiappe 2004), the Cenomanian red-beds of Morocco (e.g., Wellnhofer and Buffetaut 1999, Ibrahim et al. 2010, Rodrigues et al. 2011), the Upper Cretaceous deposits of the Goio-Erê Formation (Manzig et al. 2014), and the Maastrichtian Javelina Formation (Lawson 1975, Kellner and Langston 1996).

Here we report a new flying reptile that was recovered from the Futalognko quarry (Fig. 1), a continental deposit located about $90 \mathrm{~km}$ northwest of the Neuquén city in Argentina (Calvo et al. 2007a). The outcrops of this site are part of the Portezuelo Formation (Turonian-Early Coniacian) of the Neuquén Group (Leanza and Hugo 2001) and have yielded a diversity of fossil material, including plants (Passalia et al. 2008), osteichthyan fishes (Gallo et al. 2011), turtles, crocodylomorphs (Calvo et al. 2007a, Calvo and Porfiri 2010), titanosaur sauropods, (Calvo et al. 2007b, Calvo 2014), theropods (Calvo et al. 2004), and ornithopods. Except for the few isolated postcranial pterosaur bones reported from this site (Kellner et al. 2006), material from this volant group of archosaurs have proven to be exceedingly rare. The new specimen described here, shortly communicated before (Kellner et al. 2011), consists of an almost complete lower jaw that belongs to a distinct azhdarchoid pterosaur, Argentinadraco barrealensis gen. et sp. nov. The distinct morphology presented by this species is likely tied in with a particular feeding mode.

The ZooBank Life Science Identifier (LSID) of this publication is: urn:1sid:zoobank. org : pub:D 8 F 563 C 7 - A 82 F - 4 7 C 0 - B D 82 A725288113EF.

\section{GEOLOGICAL SETTING}

The new species comes from continental deposits from the top of the Portezuelo Formation, Río Neuquén Subgroup, Neuquén Group. The Río Neuquén Subgroup is composed of the Portezuelo
Formation that is overlain by the Plottier Formation (Cazau and Uliana 1973, Leanza 1999). Recently, the Portezuelo Formation was separated into three units, named from bottom to top Portezuelo, Los Bastos and Sierra Barrosa formations (Garrido 2010). According to this new stratigraphic arrangement, the specimens come from the upper portion of the Portezuelo Formation.

The pterosaur material was found in layers characterized by yellow sandstones, and red and green claystones, with some conglomerates, whose age has been regarded as upper Turonian Early Coniacian (Garrido 2010). The depositional environment is interpreted as a meandering river system in a flattened area of exuberant vegetation, developed in humid climate conditions (Sánchez et al. 2005). Fossils were recovered from a 20 centimeters thick green claystone within a fine conglomerate. This layer was deposited by a low energy fluvial system, as part of a meandering river where the organic remains were trapped in a point bar.

\section{SYSTEMATIC PALEONTOLOGY}

Pterosauria Kaup, 1834

Pterodactyloidea Plieninger, 1901

Azhdarchoidea Nessov, 1984

?Azhdarchidae Nessov, 1984

Argentinadraco gen. nov.

ZooBank Life Science Identifier (LSID) urn:1sid:zoobank.org:act:B62A9309-480A-4CEE95D2-CDA937EDF4B7.

Type species: Argentinadraco barrealensis gen. et sp. nov.

Etymology: From Argentina, the country where the specimen was found and draco, from the Latin meaning dragon.

Diagnosis: As for the species. 
Argentinadraco barrealensis gen. et sp. nov.

ZooBank Life Science Identifier (LSID) urn:1sid:zoobank.org:act:0DC3490E-AA4C4DB9-BF84-8F9B4256601C.

Holotype: An almost complete lower jaw housed at Centro Paleontológico Lago Barreales (CePaLB), of the Universidad del Comahue (MUCPv-1137; Figs. 2, 3).

Etymology: After Lake Barreales, where the specimen was found.

Horizon, age and locality: Portezuelo Formation, Neuquén Subgroup, Neuquén Group, Late Cretaceous, Turonian-Coniacian (Leanza and Hugo 2001). The material comes from the Futalognko site, northern coast of the Lake Barreales, Neuquén Province, Patagonia, Argentina (Fig. 1).

Diagnosis: Argentinadraco barrealensis is an azhdarchoid that presents the following autapomorphies: mandibular symphysis with marked concave ventral margin (lateral view); presence of two well-developed mandibular ridges on the dorsal surface of the posterior end of the mandibular symphysis; and a lateral sulcus on each side of the ridges. It can further be distinguished from all other azhdarchoids by possessing a small dentary sagittal crest.

\section{DESCRIPTION AND COMPARISON}

The holotype of Argentinadraco barrealensis consists of an edentulous mandible. The specimen is fragile and was prepared mechanically (Fig. 2). The right side and most of the dorsal surface was completely freed from the sedimentary matrix, but some was left in areas for protection, such as in between the mandibular rami at the posterior end of the symphysis and on the left side.

Overall, the specimen is not very well preserved. Contrary to previous pterosaur material collected at or nearby the Futalognko site (Kellner et al. 2006), MUCPv-1137 suffered from compression, particularly at the most distal part. The tip of the dentary and the posterior end of the mandibular rami are broken. The total preserved length is $259 \mathrm{~mm}$, and the size of the complete mandible is difficult to be established due to the uncertainty regarding the dimension of the mandibular rami. Nevertheless, it is clear from the preserved portion that the mandibular symphysis is very long and that the lateral compression is a natural feature and not a taphonomic artifact (Fig. 2a).

The cortical bone is thin, a typical feature of pterosaurs, and was broken and deformed in several parts. The bone surface is also not well preserved. Sutures are not observable due to fusion, a common feature of lower jaws of derived pterosaurs, where all elements, particularly the dentaries, tend to fuse very early during ontogeny (e.g., Kellner 2015). Only a small groove indicating the contact surface between the dentaries is observed on the dorsal region, close to the posterior margin of the symphysis (Figs. 2b, 3).

The dentaries comprise the main portion of the lower jaw. They are fused forming a long mandibular symphysis, which is flattened laterally. Although not complete, it is estimated that the mandibular symphysis covers over $50 \%$ of the mandible length. The dorsal margin is straight and slightly inclined downwards, similar to the condition observed in azhdarchids (Cai and Wei 1994, Kellner and Langston 1996) and differing from the upward curved lower jaw of pteranodontids (e.g., Bennett 2001) and the strong downward inclination found in some tapejarids (e.g., Wang and Zhou 2003, Kellner 2013). The dorsal surface of the preserved anterior region has blunt lateral margins separated by a faint medial sulcus. Although very compressed laterally, this region does not form the sharp blade observed in Thalassodromeus sethi Kellner and Campos, 2002 (Kellner and Campos 2002, 2007). Towards the end of the symphysis, the dorsal surface turns to a concave shelf that is flanked by a pair of lateral ridges (Fig. 3). In lateral view, these ridges and the 


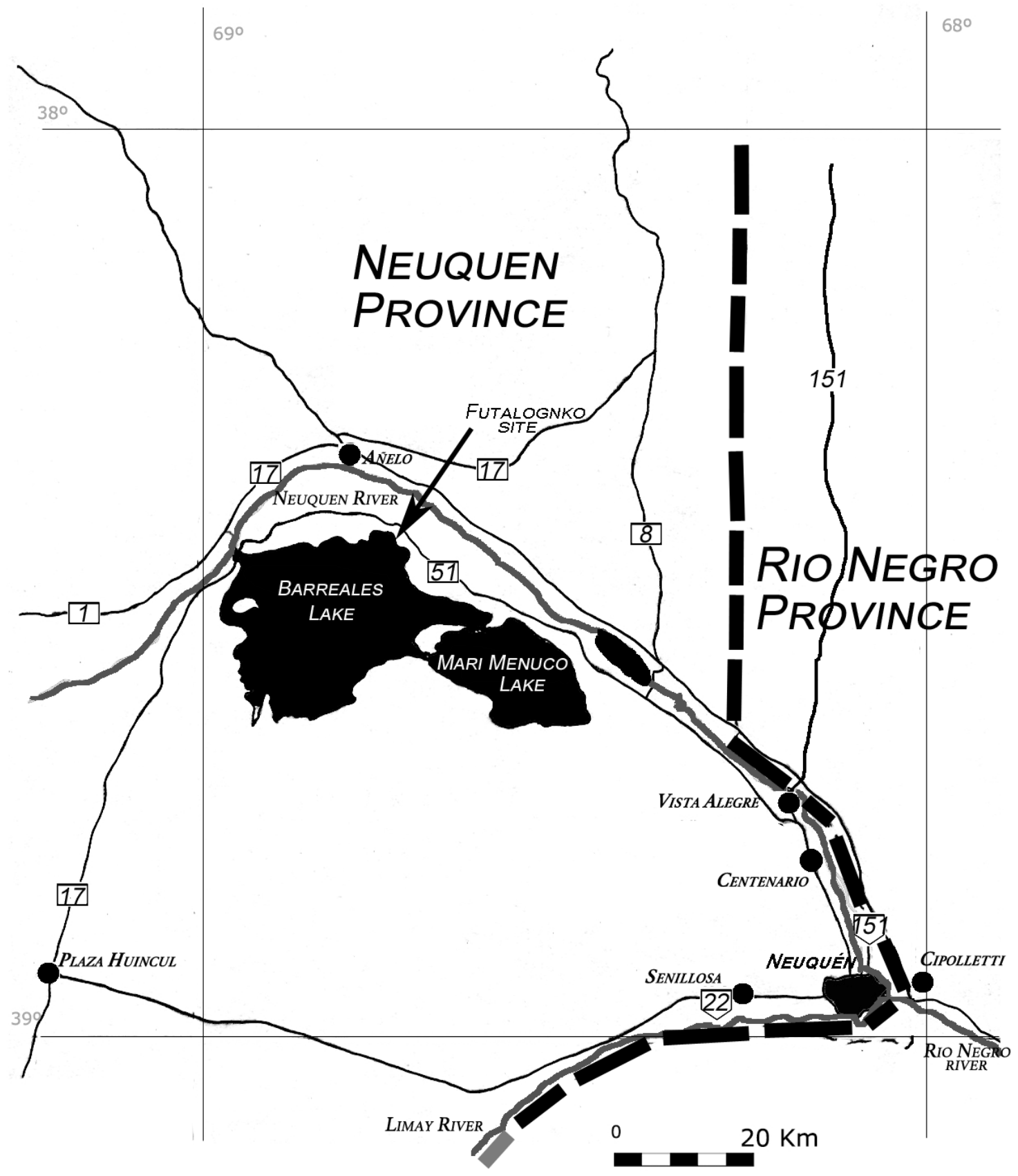

REFERENCES

INTERESTATAL BORDER

17 PROVINCE ROUTE NUMBER

Figure 1 - Map showing the locality (dark arrow) where Argentinadraco barrealensis n. gen, n. sp. was collected. 


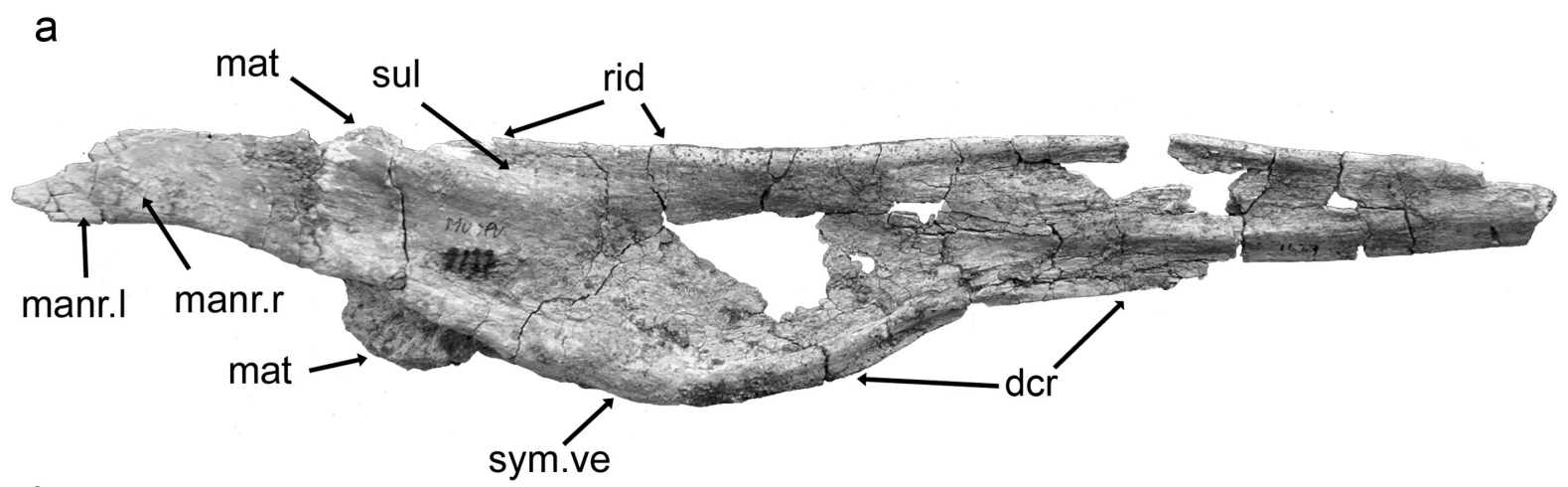

b

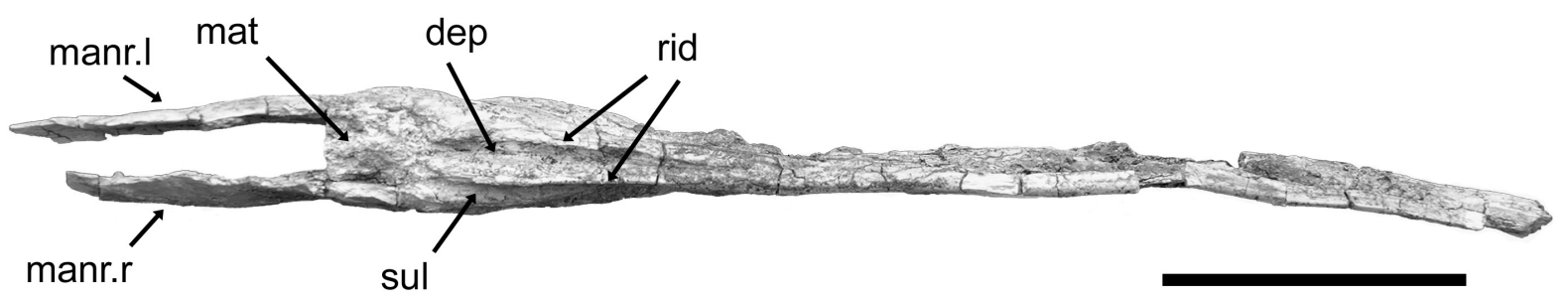

Figure 2 - Argentinadraco barrealensis n. gen, n. sp., lower jaw (MUCPv-1137), (a) right lateral view; (b) dorsal (occlusal) view. Abbreviations: dep, depression; der, dentary crest; manr, mandibular ramus; mat, matrix; rid, ridge; sul, sulcus; sym.ve, ventral segment of the symphysis; $\mathbf{1}$, left; $\mathbf{r}$, right. Scale bar equals $50 \mathrm{~mm}$.

shelf are elevated in respect to the remaining part of the symphysis and bordered by a lateral sulcus.

The symphysis gets gradually deeper posteriorly, reaching its maximum depth (44 $\mathrm{mm}$ ) at the region corresponding dorsally to the beginning of the ridges. This shape is similar to pteranodontids (e.g., Bennett 2001, Kellner 2010) and deeper than in azhdarchids (Cai and Wei 1994, Kellner and Langston 1996, Ibrahim et al. 2010) and tapejarids (e.g., Wang and Zhou 2003, Kellner 2004, 2013). The ventral margin of the symphysis is blunt and formed by thickened bone that gets more robust towards the posterior end. There is a small ventral crest in the middle portion of the lower jaw, which appears to reflect true anatomy and not a taphonomic artefact (Fig. 2a). Nonetheless, this structure is not very developed contrary to the condition observed in some tapejarids (e.g., Kellner 2004, Pinheiro et al. 2011). Argentinadraco barrealensis lacks a ventral sulcus observed in the azhdarchoid Bakonydraco Ösi et al., 2005 (Ösi et al. 2005), a likely autapomorphy of the latter.
As reported in tapejarids (Kellner 2013) and at least in some azhdarchids (Kellner and Langston 1996), the mandibular symphysis ends in two segments, forming a dentary fossa. The preserved dorsal extension of the mandibular symphysis is $\sim 193 \mathrm{~mm}$ and the ventral $\sim 160 \mathrm{~mm}$.

The mandibular rami have sharp dorsal and blunt ventral margins. They are preserved almost parallel to each other, but this is a taphonomic artifact (Fig. 2b). In lateral view, the mandibular rami are bowed posteriorly, with a concave ventral margin. It is not clear how much posterior the mandibular rami do extend. The Meckelian fossa is very shallow and no limits with other elements of the mandible are visible.

\section{DISCUSSION AND CONCLUSION}

Despite the fact that the morphological features of the lower jaw of Argentinadraco barrealensis clearly shows that it belongs to a distinct species, its assignment to any particular clade reveals to be 


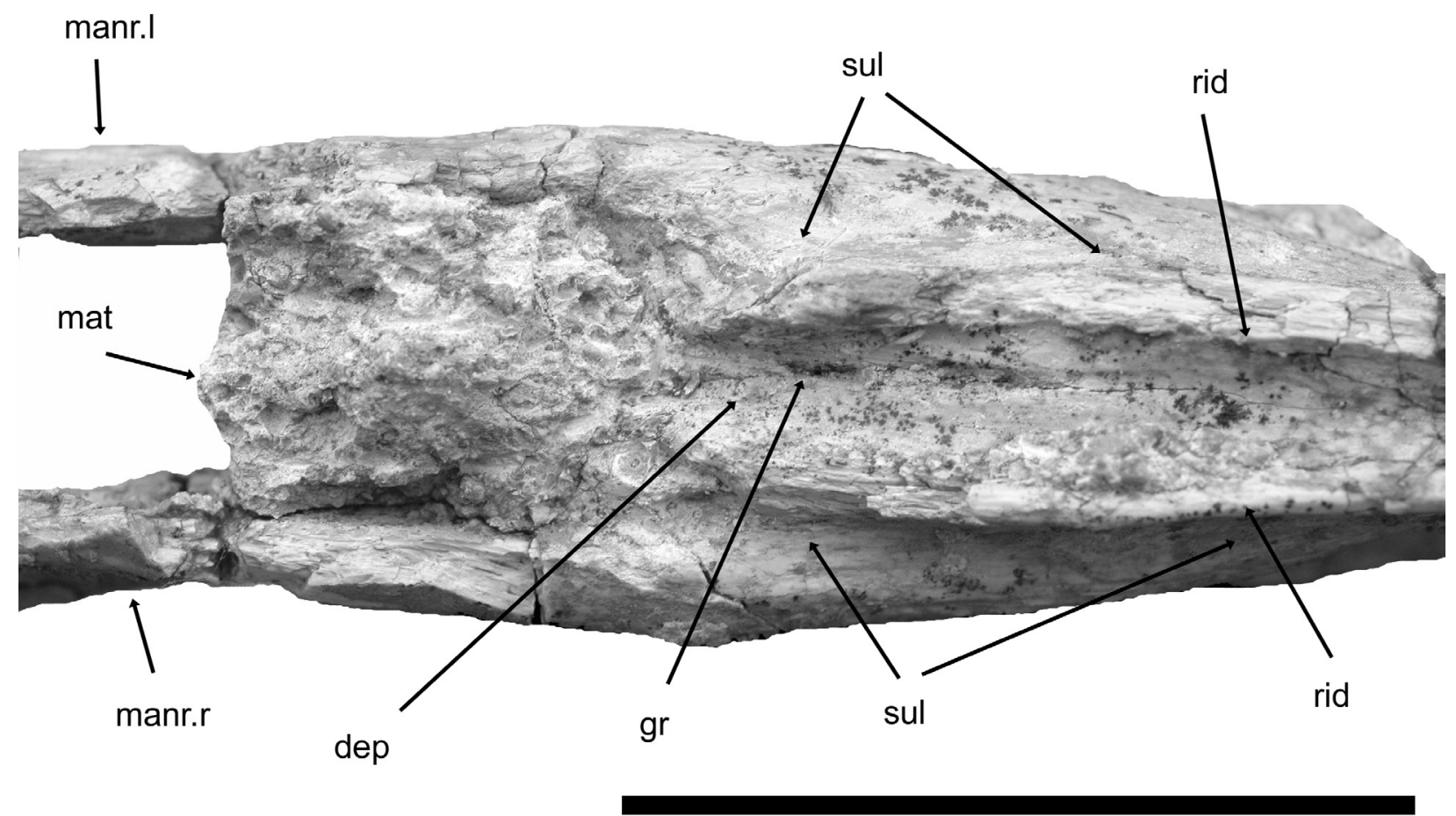

Figure 3 - Argentinadraco barrealensis n.gen, n.sp., lower jaw (MUCPv-1137). Detail of the posterior end of the mandibular symphysis in dorsal view. Abbreviations: dep, depression; gr, groove; manr, mandibular ramus; mat, matrix; rid, ridge; sul, sulcus; l, left; r, right. Scale bar equals $30 \mathrm{~mm}$.

quite challenging. All toothless pterosaurs belong to the Dsungaripteroidea (sensu Kellner 2003) and, except for Nemicolopterus Wang et al., 2008 that is regarded a basal dsungaripteroid (Wang et al. 2008), are referred to the following clades: Nyctosauridae, Pteranodontidae, Tapejaridae (Tapejarinae + Thalassodrominae), Chaoyangopteridae, and Azhdarchidae.

Although Argentinadraco barrealensis shares with the Pteranodontidae a deep posterior portion of the mandibular symphysis, the new species differs by having the deepest point at a more anterior position. Argentinadraco also lacks a large symphyseal shelf and has the anterior portion of the lower jaw slightly inclined downwards as opposed to the dorsally arched condition observed in pteranodontids. Another distinction is the presence of a developed dentary fossa in the new taxon, with the dorsal end placed posteriorly relative to the ventral one. It should be noted that although such a fossa might also be present in pteranodontids, the current interpretation suggests that the two segments of the symphysis fuse at the same level (see Bennett 2001, fig. 21).

Nyctosaurids also show a dentary fossa (e.g., see Williston 1903, fig. 1), but have a symphyseal shelf that is not present in Argentinadraco. From the available information, nyctosaurids also appear to have the dorsal margin of the lower jaw curved upwards (e.g., Bennett 2003), which constitutes another difference from the Argentinean species.

The depth of the posterior end of the mandibular symphysis is also the main feature that distinguish Argentinadraco from the basal dsungaripteroid Nemicolopterus. Although there is some taphonomic deformation of the skull of the latter, this taxon has the anterior portion of the lower (and upper) jaw downturned and lacks a dentary ventral crest, that are additional features separating it from the new species (Wang et al. 2008). 
All remaining toothless pterosaurs are part of the Azhdarchoidea (Kellner 2003, Manzig et al. 2014; but see Andres et al. 2014 for a different phylogenetic arrangement) and there is considerable variation regarding the shape of the mandible (e.g., Vullo et al. 2012, Pêgas et al. 2016). The deep posterior portion of the mandibular symphysis of the lower jaw of Argentinadraco distinguishes it from all other azhdarchoids. The new species differs from the azhdarchid Quetzalcoatlus Lawson 1975, that has a much slender and elongated lower jaw (Kellner and Langston 1996), which appears to be the condition of at least some other members of this clade (e.g., Averianov 2010, Ibrahim et al. 2010). Argentinadraco can also be excluded from the Tapejarinae that have the lower jaw downturned, with a step-like dorsal margin. Although a small sagittal crest is present in the new species, the Argentinean taxon lacks the deep dentary crest present in several tapejarines (e.g., Kellner 2004, Pinheiro et al. 2011, Vullo et al. 2012, Manzig et al. 2014). Furthermore, the mandibular rami of tapejarines are comparatively deeper and more robust than in Argentinadraco (and than in all other azhdarchoids).

The thalassodromines (Tupuxuara leonardii Kellner and Campos, 1988 and Thalassodromeus sethi) have elongated lower jaws that lack the depth of the posterior end of the mandibular symphysis found in Argentinadraco. The new species shares with Tupuxuara leonardii a small ridge-like dentary crest (Kellner 2004), but the occlusal margin of the latter is flat, with the lateral margins less blunt and lacking a medial sulcus. These features also separate Argentinadraco from Thalassodromeus that shows a blade-like occlusal surface (Kellner and Campos 2002, 2007).

Besides the already mentioned anatomical details (e.g., occlusal surface and depth of the posterior region of the mandibular symphysis), Argentinadraco differs from the tapejarids Caupedactylus Kellner, 2013 and Aymberedactylus
Pêgas et al., 2016 by having the occlusal margin of the mandible straighter and a less developed sagittal dentary crest (Kellner 2013, Pêgas et al. 2016).

In lateral view, the anterior portion of the mandibular symphysis of Argentinadraco shows similarities with the azhdarchid Zhejiangopterus Cai and Wei, 1994 and the chaoyangopterids Chaoyangopterus Wang and Zhou, 2002 and Shenzhoupterus Lü et al., 2008 (Cai and Wei 1994, Wang and Zhou 2002, Lü et al. 2008). However, as mentioned before, the unusual depth of the posterior region of the mandibular symphysis, allied with the blunt ridge-like occlusal surface and the presence of a dentary crest distinguishes the new species from these taxa.

Based on the analysis above, Argentinadraco can be excluded from Pteranodontidae, Nyctosauridae and Tapejarinae, but its allocation to one of the azhdarchoid clades Thalassodrominae, Chaoyangopteridae and Azhdarchidae is not obvious. These taxa display several cranial synapomorphies but their lower jaws are either similar (e.g., the chaoyangopterid Shenzhoupterus and the azhdarchid Zhejiangopterus) or show significant variation within members of the same clade (e.g., the thalassodromines Tupuxuara and Thalassodromeus; the azhdarchids Zhejiangopterus and Quetzalcoatlus). It is also entirely possible that Argentinadraco represents a yet unidentified clade of azhdarchoids, but the incompleteness of the material hinders a more confident assessment of the latter. Based on the overall shape of the lower jaw and on the age of the deposits where it was collected, Argentinadraco is tentatively assigned to the Azhdarchidae. It should be noted that other azhdarchoid material was also recovered from this site (Kellner et al. 2006), which Codorniú and Gasparini (2007) classified in the Azhdarchidae.

Other azhdarchid material from Argentina consists of an incomplete jaw fragment from the Campanian-Maastrichtian Allen Formation, Rio 
Negro Province (Novas et al. 2012). Although in the original description this specimen was considered an upper jaw based on the fact that the occlusal margin is slightly downturned it might actually represent the anterior portion of a dentary. In any case, comparisons with Argentinadraco are restricted, but judging from the limited information available, Aerotitan Novas et al., 2012 appears to have had slender and elongated jaws, similar to those of the azhdarchid Quetzalcoatlus.

Although it is always very difficult to make inferences about the feeding habits of extinct vertebrates, the unusual systems of paired ridges separated by a depression and bordered laterally by a marked sulcus present in Argentinadraco barrealensis hints for an elaborate interlocking mechanism with the upper jaw. The unusually deep posterior portion of the lower jaw suggests strong bite forces, as has been hypothesized for Pteranodon Marsh, 1876 (Bennett 2001). The occlusal surface of the anterior portion of the mandibular symphysis forming blunt lateral edges divided by a medial sulcus differs from the flattened or concave condition observed in several other edentulous pterosaurs. Admittedly speculative, it is possible that Argentinadraco barrealensis used the lower jaw to cut or plough trough unconsolidated sediment of shallow waters (rivers or lakes) in order capture prey (e.g., soft-bodied invertebrates, crustaceans). If correct, this indicates a rather terrestrial feeding habit, as has been interpreted for azhdarchids in general (e.g., Witton 2007, Witton and Naish 2008, Averianov 2013).

In conclusion, despite incomplete, the discovery of the lower jaw described here adds to the diversity of South American Cretaceous pterosaur occurrences and further provides new information about the variation of the lower jaw morphology of azhdarchoid pterosaurs.

\section{ACKNOWLEDGMENTS}

We thank Duke Energy Argentina, Duke University and United Way International for developing and supporting the Proyecto Dino and research at the new Centro Paleontológico Lago Barreales (CePaLB) for the time when this specimen was collected, almost a decade ago. AWAK wants to acknowledge Juan Porfiri and Domenica Santos for previous discussions regarding this material. We also thank three anonymous reviewers for their suggestions. This project was supported by the National University of Comahue 04-I-182/2013 and PIN- I -231/2017; Agencia Nacional de Promoción Científica y Tecnológica project PICT 2011-2591 (to JOC); oil company Chevron S.A. and Fundación Luciérnaga (Proyecto Dino to JOC); Conselho Nacional de Desenvolvimento Científico e Tecnológico, (CNPq \# 304780/2013-8 to AWAK) and Fundação Carlos Chagas Filho de Amparo à Pesquisa do Estado do Rio de Janeiro (FAPERJ \# E-26/202.893/2015 to AWAK).

\section{REFERENCES}

ANDRES B, CLARK J AND XU X. 2014. The earliest pterodactyloid and the origin of the group. Curr Biol 24: 1011-1016.

AVERIANOV AO. 2010. The osteology of Azhdarcho lancicollis Nessov, 1984 (Pterosauria, Azhdarchidae) from the Late Cretaceous of Uzbekistan. Proceedings of the Zoological Institute of the Russian Academy of Sciences 314: 264-317.

AVERIANOV AO. 2013. Reconstruction of the neck of Azhdarcho lancicollis and lifestyle of azhdarchids. Paleontological Journal 47: 203-209.

BAKHURINA NN AND UNWIN DM. 1995. A survey of pterosaurs from the Jurassic and Cretaceous of the former Soviet Union and Mongolia. Hist Biol 10: 197-245.

BARRETT PM, BUTLER RJ, EDWARDS NP AND MILNER AR. 2008. Pterosaur distribution in time and space: an atlas. Zitteliana 28: 61-108.

BENNETT SC. 2001. The osteology and functional morphology of the Late Cretaceous pterosaur Pteranodon. Palaeontogr Abt A 260: 1-112.

BENNETT SC. 2003. New crested specimens of the Late Cretaceous pterosaur Nyctosaurus. Pal Zeit 77: 61-75. 
BONAPARTE JF. 1971. Descripción del craneo y mandibulas de Pterodaustro guinazui (Pterodactyloidea Pterodaustriidae nov.) de la formación Lagarcito, San Luis, Argentina. Public Museo Municipal de Ciénc Naturales 1: 263-272.

CAI Z AND WEI F. 1994. On a new pterosaur (Zhejiangopterus linhaiensis gen. et sp. nov.) from Upper Cretaceous in Linhai, Zhejiang, China. Vertebrat Palasiatic 32: 181-194.

CALVO JO. 2014. New Fossil Remains of Futalognkosaurus dukei (Sauropoda, Titanosauria) From the Late Cretaceous of Neuquén, Argentina. IV International Paleontological Congress. Mendoza, Sept 2014. Cd rom.

CALVO JO AND PORFIRI JF. 2010. New material of Peirosaurids from Neuquén, Patagonia: its age. Brazilian Geographical Journal: Geosciences and Humanities research medium 1: 50-64.

CALVO JO, PORFIRI JD, GONZÁLEZ-RIGA BJ AND KELLNER AWA. 2007a. A new Cretaceous terrestrial ecosystem from Gondwana with the description of a new sauropod dinosaur. An Acad Bras Cienc 79: 529-541.

CALVO JO, PORFIRI JD, GONZÁLEZ-RIGA BJ AND KELLNER AWA. 2007b. Anatomy of Futalognkosaurus dukei Calvo, Porfiri, Gonzalez Riga, Kellner, 2007 (Dinosuria, Titanosauridae) from the Neuquén Group (Late Cretaceous), Patagonia, Argentina. Arq Mus Nac, Rio de Janeiro, RJ, Brazil 65(4): 511-526.

CALVO JO, PORFIRI JD, VERALLI C, NOVAS F AND POBLETE F. 2004. Phylogenetic status of Megaraptor namunhuaiquii Novas based on a new specimen from Neuquén, Patagonia, Argentina. Ameghiniana 41: 565575.

CAZAU LB AND ULIANA MA. 1973. El Cretácico superior continental de la Cuenca Neuquina. V Congreso Geológico Argentino, Buenos Aires, Actas 3: 131-163.

CHIAPPE LM, KELLNER AWA, RIVAROLA D, DAVILA S AND FOX M. 2000. Cranial morphology of Pterodaustro guinazui (Pterosauria: Pterodactyloidea) from the Lower Cretaceous of Argentina. Natural History Museum of Los Angeles County, Contributions in Science 483: 1-19.

CODORNIÚ L AND CHIAPPE LM. 2004. Early juvenile pterosaurs (Pterodactyloidea: Pterodaustro guinazui) from the Lower Cretaceous of central Argentina. Can J Earth Sci 41: 9-18.

CODORNIÚ L AND GASPARINI Z. 2007. Pterosauria; p. 143-166 in Gasparini Z, Salgado L and Coria R (Eds), Patagonian Mesozoic Reptiles. Indiana University Press, Bloomington and Indianapolis, Indiana.

GALLO V, CALVO JO AND KELLNER AWA. 2011. First record of a clupeomorph fish in the Neuquén Group (Portezuelo Formation), Upper Cretaceous of Patagonia, Argentina. Cretaceous Res 32: 223-235.

GARRIDO AC. 2010. Estratigrafía del Grupo Neuquén: Cretácico superior de Cuenca Neuquina: nueva propuesta de ordenamiento litoestratigráfico. Rev Mus Cienc Nat Argent 12: 121-177.

IBRAHIM N, UNWIN DM, MARTILLDM, BAIDDER LAND ZOUHRI S. 2010. A New Pterosaur (Pterodactyloidea: Azhdarchidae) from the Upper Cretaceous of Morocco. PLoS ONE 395 5(5): e10875.

KELLNER AWA. 1994. Remarks on pterosaur taphonomy and paleoecology. Acta Geol Leopold 39: 175-189.

KELLNER AWA. 2003. Pterosaur phylogeny and comments on the evolutionary history of the group. In: Buffetaut E and Mazin JM (Eds), Evolution and palaeobiology of pterosaurs. London: Geological Society, p. 105-137. (Special Publication, 217).

KELLNER AWA. 2004. New information on the Tapejaridae (Pterosauria, Pterodactyloidea) and discussion of the relationships of this clade. Ameghiniana 41: 521-534.

KELLNER AWA. 2010. Comments on the Pteranodontidae (Pterosauria, Pterodactyloidea) with the description of two new species. An Acad Bras Cienc 82: 1063-1084.

KELLNER AWA. 2013. A new unusual tapejarid (Pterosauria, Pterodactyloidea) from the Early Cretaceous Romualdo Formation, Araripe Basin, Brazil. Earth and Environmental Science Transaction of the Royal Society of Edinburgh 103: 409-421.

KELLNER AWA. 2015. Comments on Triassic perosaurs with discussion about ontogeny and description of new taxa. An Acad Bras Cienc 87: 669-689.

KELLNER AWA, CALVO JO, PORFIRI JD AND DOS SANTOS D. 2011. An Azharchoid lower jaw (Pterosauri, Pterodactyloidea) from the Portezuelo Formation (Cretaceous), Neuquén Group, Patagonia, Argentina. IV Congreso Latinoamericano de Paleontologia de Vertebrados. Septiembre, CD Rom. San Juan.

KELLNER AWA, CALVO J, SAYÃO JM AND PORFIRI JD. 2006. Pterosaur bones from the Portezuelo Formation (Cretaceous), Neuquén Group, Patagonia, Argentina. Arq Mus Nac 64: 369-375.

KELLNER AWA AND CAMPOS DA. 2002. The function of the cranial crest and jaws of a unique pterosaur from the Early Cretaceous of Brazil. Science 297: 389-392.

KELLNER AWA AND CAMPOS DA. 2007. Short note on the ingroup relationships of the Tapejaridae (Pterosauria, Pterodactyloidea). Bol Mus Nac, Geol 75: 1-14.

KELLNER AWA AND LANGSTON JR W. 1996. Cranial remains of Quetzalcoatlus (Pterosauria, Azhdarchidae) from the Late Cretaceous Sediments of Big Bend National Park, Texas. J Vert Paleont 16: 222-231.

LAWSON DA. 1975. Pterosaur from the latest Cretaceous of West Texas: discovery of the largest flying creature. Science 187: 947-948.

LEANZA HA. 1999. The Jurassic and Cretaceous Terrestrial Beds from Southern Neuquén Basin, Argentina. Miscelanea, Tucumán 4: 1-30. 
LEANZA HA AND HUGO CA. 2001. Cretaceous red beds from southern Neuquén Basin (Argentina): age, distribution and stratigraphic discontinuities. In: Leanza HA (Ed), VII International Symposium on Mesozoic Terrestrial Ecosystems. Buenos Aires: Asociación Paleontológica Argentina 7: 117-122.

LÜ J AND JI Q. 2006. Preliminary results of a phylogenetic analysis of the pterosaurs from western Liaoning and surrounding areas. J Paleont Soc Korea 22: 239-261.

LÜ J, UNWIN D, XU L AND ZHANG Z. 2008. A new azhdarchoid pterosaur from the Lower Cretaceous of China and its implication for pterosaur phylogeny and evolution. Naturwissenschaften 95: 891-897.

MANZIG PC, KELLNER AWA, WEINSCHÜTZ LC, FRAGOSO CE, VEGA CS, GUIMARÃES GB, GODOY LC, LICCARDO A, RICETTI JH AND DE MOURA CC. 2014. Discovery of a rare bone bed in a Cretaceous desert with insights on ontogeny and behavior of flying reptiles. PLoS ONE 9: e100005.

NOVAS FE, KUNDRAT M, AGNOLÍN FL, EZCURRA MD, AHLBERG PE, ISASI MP, ARRIAGADA A AND CHAFRAT P. 2012. A new large pterosaur from the Late Cretaceous of Patagonia. J Ver Paleont 32: 1447-1452.

ÖSI A, WEISHAMPEL DB AND JIANU CM. 2005. First evidence of azhdarchid pterosaurs from the Late Cretaceous of Hungary. Acta Palaeontol Pol 50: 777-787.

PASSALIA MG, PRÁMPARO MB, CALVO JAND HEREDIA S. 2008. Primer registro de hojas de angiospermas en el Grupo Neuquén (Turoniano tardío-Coniaciano temprano), Lago Barreales, Argentina. Ameghiniana 45: 233-240.

PÊGAS RV, LEAL MEC AND KELLNER AWA. 2016. A basal Tapejarine (Pterosauria; Pterodactyloidea; Tapejaridae) from the Crato Formation, Early Cretaceous of Brazil. PLoS ONE 11(9): e0162692.

PINHEIRO FL, FORTIER DC, SCHULTZ CL, ANDRADE JAFG AND BANTIM RAM. 2011. New information of the pterosaur Tupandactylus imperator, with comments on the relationships of Tapejaridae. Acta Palaeontol Pol 56: $567-580$.

RODRIGUES T AND KELLNER AWA. 2013. Taxonomic review of the Ornithocheirus complex (Pterosauria) from the Cretaceous of England. ZooKeys (Monographs) 308: $1-112$.

RODRIGUES T, KELLNER AWA, MADER BJ AND RUSSELL D. 2011. New pterosaur specimens from the Kem Kem beds (Upper Cretaceous, Cenomanian) of Morocco. Riv Italiana di Paleont e Stratigrafia 117(1): 149-160.

SÁNCHEZ ML, CALVO J AND HEREDIA S. 2005. Paleoambientes de sedimentación del tramo superior de la Formación Portezuelo, Grupo Neuquén (Cretácico Superior), Los Barreales, provincia de Neuquén. Rev Asoc Geol Argent 60: 142-158.
SULLIVAN C, WANG Y, HONE DWE, WANG Y, XU X AND ZHANG F. 2014. The vertebrates of the Jurassic Daohugou Biota of northeastern China. J Vert Pal 34: 243280.

VULLO R, MARUGÁN-LOBÓN J, KELLNER AWA, BUSCALIONI AD, GOMEZ B, DE LA FUENTE M AND MORATALLA JJ. 2012. A New Crested Pterosaur from the Early Cretaceous of Spain: The First European Tapejarid (Pterodactyloidea: Azhdarchoidea). PLoS ONE 7(7): e38900.

WANG X ET AL. 2015. Eggshell and histology provide insight on the life history of a pterosaur with two functional ovaries. An Acad Bras Cienc 87: 1599-1609.

WANG X ET AL. 2014. Sexually Dimorphic Tridimensionally Preserved Pterosaurs and Their Eggs from China. Curr Biol 24: 1323-1330.

WANG X, KELLNER AWA, ZHOU Z AND CAMPOS DA. 2005. Pterosaur diversity and faunal turnover in Cretaceous terrestrial ecosystems in China. Nature 437: 875-879.

WANG X, KELLNER AWA, ZHOU Z AND CAMPOS DA. 2008. Discovery of a rare arboreal forest-dwelling flying reptile (Pterosauria, Pterodactyloidea) from China. Proc Nat Acad Sci 105: 1983-1987.

WANG X AND ZHOU ZH. 2006. Pterosaur assemblages of the Jehol Biota and their implication for the Early Cretaceous pterosaur radiation. Geol J 41: 405-418.

WANG XL, KELLNER AWA, JIANG SX AND CHENG X. 2012. New toothed flying reptile from Asia close similarities between early Cretaceous pterosaur faunas from China and Brazil. Naturwissenschaften 99: 249-257.

WANG XL AND ZHOU ZH. 2002. Two new pterodactyloid pterosaurs from the Early Cretaceous Jiufotang Formation of western Liaoning China. Vertebrat PalAsiatic 41: 34-41.

WANG XL AND ZHOU ZH. 2003. A new pterosaur (Pterodactyloidea Tapejaridae) from the Early Cretaceous Jiufotang Formation of western Liaoning China and its implications for biostratigraphy. Chin Sci Bull 48: 16-23.

WELLNHOFER P. 1991. The illustrated encyclopedia of Pterosaurs. London: Salamander Books, 192 p.

WELLNHOFER P AND BUFFETAUT E. 1999. Pterosaur remains from the Cretaceous of Morocco. Pal Zeit 73: 133142.

WILLISTON SW. 1903. On the osteology of Nyctosaurus (Nyctodactylus), with notes on American pterosaurs. Field Columbian Museum Public, Geol Ser 2(3): 125-163.

WITTON MP. 2007. Titans of the Skies: Azhdarchid Pterosaurs. Geol Today 23: 33-38.

WITTON MP AND NAISH D. 2008. A Reappraisal of Azhdarchid Pterosaur Functional Morphology and Paleoecology. PLoS ONE 3(5): e2271. 